University of Nebraska - Lincoln

DigitalCommons@University of Nebraska - Lincoln

Agronomy \& Horticulture -- Faculty Publications

Agronomy and Horticulture Department

2004

\title{
Genotypic and Environmental Modification of Asian Noodle Quality of Hard Winter Wheats
}

Robert A. Graybosch

University of Nebraska-Lincoln, bob.graybosch@ars.usda.gov

N. Ames

Agriculture and Agrifood Canada

P. Stephen Baenziger

University of Nebraska-Lincoln, pbaenziger1@unl.edu

C. J. Peterson

Oregon State University

Follow this and additional works at: https://digitalcommons.unl.edu/agronomyfacpub

Part of the Plant Sciences Commons

Graybosch, Robert A.; Ames, N.; Baenziger, P. Stephen; and Peterson, C. J., "Genotypic and Environmental Modification of Asian Noodle Quality of Hard Winter Wheats" (2004). Agronomy \& Horticulture -- Faculty Publications. 594.

https://digitalcommons.unl.edu/agronomyfacpub/594

This Article is brought to you for free and open access by the Agronomy and Horticulture Department at DigitalCommons@University of Nebraska - Lincoln. It has been accepted for inclusion in Agronomy \& Horticulture -Faculty Publications by an authorized administrator of DigitalCommons@University of Nebraska - Lincoln. 


\title{
Genotypic and Environmental Modification of Asian Noodle Quality of Hard Winter Wheats ${ }^{1}$
}

\author{
R. Graybosch, ${ }^{2}$ N. Ames, ${ }^{3}$ P. S. Baenziger,${ }^{4}$ and C. J. Peterson ${ }^{5}$
}

\section{ABSTRACT}

Cereal Chem. 81(1):19-25

The relative effects of environment, genotype, and their interactions on the modification of Asian noodle quality attributes were assessed using 38 winter wheat (Triticum aesfivum $\mathrm{L}$.) cultivars and breeding lines grown in replicated trials at three Nebraska locations in harvest year 2000. Noodle color was determined in both white salted and yellow alkaline procedures, and noodle textural features were investigated by producing white salted noodles. Significant environmental, genotypic, and genotype-by-environment variation was observed for nearly all initial and 24-hr noodte color traits in both types of noodles. Significant genotypic effects were observed for several textural traits, while significant environmental effects were observed only for noodle hardness and water uptake. However, among the noodle textural traits, the genotype-by-cnvironment interaction was significant only for noodle firmness. High and significant phenotypic correlations were observed between color traits in the two noodle applications. Genetic correlations were of lower magnitude, indicating the possibility of brecding wheats specifically for various noodle color types. Strong negative phenotypic and genetic correlations were observed between flour protein content and noodle brightness ( $\mathrm{L}^{*}$ ) values in both yellow alkaline and white-salted applications. Textural traits largely were independent of noodle color traits. When significant phenotypic or genetic correlations were observed between variable pairs, invariably similar corrclations were observed with flour protein content. Noodle cutting force, cutting area, and final thickness showed strong phenotypic and genetic correlations with each other and with protein content. These variables largely were independent of noodle firmness and hardness, which were, in turn, more dependent on alleles at the wheat $w x-A l$ and $w x-B /$ (waxy) loci. Noodle firmness wals greatest in flours from wild-type wheats; lines with a null allele only at the $w x$-Al locus did not differ from wild-type. Softest noodles were produced from lines carrying null alleles at both $w x-A /$ and $w x-B /$, while lines with a null only at $w x-B /$ were intermediate in softness.
For the past century, wheat (Triticum acstivum L.) breeders in the Great Plains of North America have strived to develop high quality wheats suitable for the production of leavened bakery products, primarily pan breads. Of late, more attention has been paid to the fact that hard wheats can function in more products than bread alone. Due both to changing cultural tastes in North American markets and a desire to more effectively compete in export markets, North American wheat breeders have begun to focus attention on the breeding of wheats for use in Asian noodle products. Quality requirements for noodle products differ from those of bread products (Kruger 1996); hence, it is important to establish procedures and criteria for the development of wheats with acceptable noodle quality.

To effectively develop improved quality wheats, wheat breeders require an understanding of the extent to which quality characteristics of the finished products are delermined by environmental factors (E), genetic factors (genotype, G), and their interactions. Traits with high genetic components are most amenable to improvement by selection (Falconer 1960). The modifications of wheat functional properties by environment and $\mathrm{G} \times \mathrm{E}$ interactions have been well documented for a number of wheat classes and products (Baenziger et al 1985; Bassett et al 1989; Peterson et al 1998). Surprisingly, little information is available on the relative effects of genotype, environment, and their interactions on Asian noodle quality. Morris et al (1997) documented the extent of such effects on flour swelling volume, a trait related to noodle-making quality, but did not measure the direct effects by producing noodles.

\footnotetext{
Ioint contribution of the United States Department of Agriculture, Agriculture Research Service and the Universily of Nebraska Agriculture Research Division as Journal Series Paper No. 1397.3. Mention of firm names or trade products does not inply that they are endorsed or recommended by the University of Vebraska or USDA over other firms or products not mentioned.

2 USDA-ARS, 344 Keim, University of Nebraska, lincoln, NE 68583. Corresponding author. E-mail; rag@unlserve.unl.edu.

${ }^{3}$ Agriculture and Agrilood Canada, Winnipeg, Manitoba.

4 Department of $A$ gromomy \& Horticulture, University of Nebraska, Lincoln, NE.

${ }^{5}$ Department of Crop \& Soil Science, Oregon State University, Corvallis, OR.
}

Publication no, C-2003-1110-05R.

This article is in the public domain and not copyrightable. It may be freely reprinted with customary crediting of the source. American Association of Cereal Chemists, Inc., 2004.
Habernicht et al (2002) found that environments favoring higher flour protein concentrations diminished both initial and final noodle brightness. However, the relative magnitudes of the environmental, genotypic, and $\mathrm{G} \times \mathrm{E}$ interactions were not established. Such information is crucial to the effective design of strategies to develop wheats with improved noodle quality.

Full-scale noodle quality evaluations are not practical during early stages of breeding programs. For breadmaking quality, hard wheat breeders have relied on small-scale tests to identify lines in early generations with the potential to produce high-quality finished products. Such assays include various measures of flour protein concentration and quality, allelic status at loci encoding HMW glutenin proteins, SDS sedimentation volumes, and theological devices such as the mixograph. For noodles, the importance of grain polyphenol oxidases as a factor contributing to discoloration has been well documented (Anderson and Morris 2001). For noodle textural features, flour swelling tests (Crosbie and Lambe 1993), flour pasting properties as measured by the Rapid Visco Analyser (Bhattacharya and Corke 1996; Batey et al 1997), or the presence of null alleles at the three wheat waxy (wx) loci (Epstein et al 2002) all have been proposed as possible early generation tools. Within specific sample sets, each of these assays has been correlated with noodle textural properties. The $w x$ loci condition the production of isoforms of the granule-bound starch synthase (GBSS), the enzyme responsible for amylose production in cereal endosperms. Null alleles at thesc loci are related to changes in flour amylose content (Miura et al 1994).

The goals of this investigation, then, were to document the relative effects of environmental, genotypic, and $\mathrm{G} \times \mathrm{H}$ interactions on noodle quality traits, and to determine to what extent genotypic variation was related to flour protein concentration, grain hardness, and allelic status at the wx loci.

\section{MATERIALS AND METHODS}

\section{Plant Materials}

Thirty-eight hard winter wheat cultivars and experimental breeding lines were grown (2000 harvest year) at three locations: Lincoln, McCook, and Sidney, Nebraska. The sample set included the hard white cultivars Lakin and Trego, the hard red cultivars Redland, Vista, Arapahoe, and TAM-202, and 31 experimental winter wheat 
breeding lines produced by the winter wheat breeding program of the University of Nebraska. The lines were seeded in three replicate randomized complete blocks at each location, and fertilized under typical cultural conditions. No supplemental irrigation was applied.

\section{Grain and Flour Quality Traits}

$W x$ allelic status of all lines was established by electrophoretic analysis and silver-staining of the waxy (GBSS) proteins (Graybosch et al 1998).

Grain was milled to flour on the Brabender Quadraplex mill (S. Hackensack, NJ). Flour protein concentration was measured with near-infrared reflectance (NIR, Approved Method 39-11, AACC 2000 ). Laboratory values for protein concentration and subsequent equation development and calibration checks were determined by the nitrogen combustion method (Approved Method 46-30, AACC 2000). The SKCS (Single Kernel Characterization System, Perten Instruments, Springfield, IL) was used to determine average kernel hardness and weight (Approved Method 55-31, AACC 2000).

\section{Preparation of White Salted and Yellow Alkaline Noodles for Color Analysis}

White salted noodles were made from $10 \mathrm{~g}$ of wheat flour $(14 \%$ moisture, fwb) by adding $4.0 \mathrm{~mL}$ of $2 \%(\mathrm{w} / \mathrm{v}) \mathrm{NaCl}$ solution directly to the flour after $30 \mathrm{sec}$ of dry mixing in a farinographtype paddle mixer (10-g microfarinograph developed at Agriculture and Agri-food Canada, Winnipeg, MB, Canada). Yellow alkaline noodles were made by adding $4.0 \mathrm{~mL}$ of $1 \%$ (w/v) $\mathrm{Na}_{2} \mathrm{CO}_{3}$ solution to $10 \mathrm{~g}$ of flour ( $14 \%$ moisture, fwb) after $30 \mathrm{sec}$ of dry mixing. The volume of solution added achieved $40 \%$ absorption. After the addition of solution, doughs were mixed for 3 min. The crumbly dough was kneaded by hand for $1 \mathrm{~min}$, pressed into a cohesive rectangular block, and passed twice through a laboratory sheeting machine (CDR-100S, Somerset Industries Inc., Billerica, MA) to obtain a sheet thickness of $1.5 \mathrm{~mm}$.

Immediately after sheeting, the dough sheets were placed on a white tile and color was measured using a colorimeter (Chroma Meter CR-210, Minolta Camera Co. Ltd, Osaka, Japan). Minolta $\mathrm{L}^{*}$ (brightness), $\mathrm{a}^{*}$ (redness), and $\mathrm{b}^{*}$ (yellowness) values were recorded. Dough sheets were enclosed in plastic bags, the time of first color measurement was recorded, and they were kept at room temperature $\left(25^{\circ} \mathrm{C}\right)$ for $24 \mathrm{hr}$. After $24 \mathrm{hr}$, the dough sheets werc reanalyzed by placing the colorimeter in the exact spot as previously measured and obtaining the Minolta $L^{*}, a^{*}$, and $b^{*}$ values.

\section{White Salted Noodle Textural Analysis}

White salted noodles were made from $25 \mathrm{~g}$ of wheat flour $(14 \%$ moisture, fwb) by adding $2 \%(\mathrm{w} / \mathrm{v}) \mathrm{NaCl}$ solution according to a gross water calculation to ensure that moisture and dry weight proportions wcre consistent: $[25 \mathrm{~g}+(25 \mathrm{~g} \times 31 \% \mathrm{abs})]-$ corrected flour weight (g) (Kilborn and Tipples 1981). Doughs were mixed in a standard pin mixer (35-g mixograph, head speed $90 \mathrm{rev} / \mathrm{min}$, Engineering Research Service, Canada Agriculture, Ottawa, ON, Canada) for $5 \mathrm{~min}$. The crumbly dough was kneaded by hand for

\section{TABLE I}

Mean Square Values from Analysis of Variance, Grain, and Flour Quality Traits of 38 Hard Winter Wheats Grown at Three Nebraska Locations in $2000^{\mathrm{a}}$

\begin{tabular}{lcccc}
\hline $\begin{array}{l}\text { Source of } \\
\text { Variation }\end{array}$ & df & $\begin{array}{c}\text { Grain } \\
\text { Weight }\end{array}$ & $\begin{array}{c}\text { Grain } \\
\text { Hardness }\end{array}$ & $\begin{array}{c}\text { Flour } \\
\text { Protein }\end{array}$ \\
\hline Environment $(\mathrm{E})$ & 2 & $658.2^{*}$ & $1,793^{*}$ & $206.25^{*}$ \\
Replicate within E & 6 & $53.2^{*}$ & $71^{*}$ & $13.61^{*}$ \\
Genotype & 37 & $16.8^{*}$ & $160^{*}$ & $3.08^{*}$ \\
GBSS alleles & 3 & $12.0^{*}$ & 86 & 0.29 \\
Line $\times$ E & 74 & $2.4^{*}$ & $35^{*}$ & 1.03 \\
GBSS alleles $\times \mathrm{E}$ & 6 & 1.0 & 18 & 1.15 \\
Error & 216 & 1.4 & 18 & 1.1 \\
\hline
\end{tabular}

a *, Significant at $P=0.05$.
1 min, pressed into a cohesive rectangular block, and passed through a laboratory noodle machine (Agriculture \& Agrifood Canada, Winnipeg, MB, Canada) with an initial gap of $4 \mathrm{~mm}$. The sheet was marked to indicate direction of insertion into rolls, cut in half, and the pieces were placed one on top of the other. Continuing in the original direction of sheeting, the dough pieces were passed through the roller again at $4 \mathrm{~mm}$, enclosed in a plastic bag, and left to rest for $20 \mathrm{~min}$. The sheet was then progressively reduced by sheeting at $2.5,1.5$, and $1.0 \mathrm{~mm}$. Sheet thickness was measured $90 \mathrm{sec}$ after the $1.0-\mathrm{mm}$ pass by taking the average of five caliper measurements (Peacock Dial Thickness Gauge G, Ozaki Mfg. Co., Ltd., Ozaki, Japan). Sheet length was measured $2.5 \mathrm{~min}$ after the $1.0-\mathrm{mm}$ pass. Representative test strips $(4 \mathrm{~cm})$ were cut from each end and used to adjust the roller gap to achieve a final noodle thickness of $1.3 \pm 0.05 \mathrm{~mm}$. The dough sheet was then passed through the rollers at the adjusted gap setting and final sheet thickness was measured after $90 \mathrm{sec}$. The dough sheet was then cut into noodles $6 \mathrm{~mm}$ wide $\times 6 \mathrm{~cm}$ long (Roscan de luxe Pasta Machine, G. Rosenthal Import Ltd., Montreal, QB, Canada), discarding noodles made from the outer edges of the dough sheet. Noodles were cooked for $9 \mathrm{~min}$ in $1 \mathrm{~L}$ of boiling distilled water. After $9 \mathrm{~min}$, the noodles were poured into a wire sieve and the sieve was placed in a shallow pan of $25^{\circ} \mathrm{C}$ distilled water for $2 \mathrm{~min}$, moved to a new pan of $25^{\circ} \mathrm{C}$ distilled water for an additional $2 \mathrm{~min}$, then tapped gently over a beaker five times to remove excess water. Four marked noodle pieces were weighed to determine cooked weight and discarded. Percent water uptake was calculated as [cooked wt $(\mathrm{g})$ - raw wt $(\mathrm{g})$ ] / raw wt $(\mathrm{g}) \times 100$. The remaining noodles were placed on parchment paper inside a plastic container and covered for $2 \mathrm{~min}$ before testing.

A texture analyzer (TA-XT2i, Texture Technologies, Scarsdale, NY) equipped with a Windows version of Texture Expert software package (Stable Micro Systems, Scarsdale, NY) was used to measure noodle thickness, cutting force, firmness, and to conduct texture profile analysis (TPA) of the white salted noodles. For all measurements, the TA-XT2i was equipped with a 25 -g load cell. To determine cutting force, three 6-cm long strands were oriented perpendicular to the pasta blade probe (TA-47) on the flat aluminum platform base (TA-90A), such that each noodle was in contact with the next. The probe deseended through the noodles at speed of $0.8 \mathrm{~mm} / \mathrm{sec}$ until it reached a force of $1,800 \mathrm{~g}$ (touched the base), and was retracted to end the test. The test was repeated two more times at different locations on the same three noodles to obtain an average. For noodle firmness, noodles were oriented as described above. The probe (TA-47) descended $1 \mathrm{~mm}$ into the noodles at a speed of $1.0 \mathrm{~mm} / \mathrm{sec}$ and was retracted to end the test. Firmness was measured as the peak force of the curve. The test was repeated two more times at different locations and the results were averaged. Noodles were oriented for TPA as described above. A blunt Plexiglass blade probe (9-mm contact surface) was fixed to the pasta blade probe mount. The probe compressed the noodles at a rate of $0.45 \mathrm{~mm} / \mathrm{sec}$ to $70 \%$ strain. The probe was retracted and held stationary for $3 \mathrm{sec}$ before performing a second compression. Two additional sets of three noodles were subjected to TPA measurements, and results from each test were averaged. The variables recorded were noodle hardness, stickiness force, stickiness area, springiness, and resiliency. TPA variables were identical to those reported by Epstein et al (2002), except that "area 4" is herein termed "stickiness area" and stickiness force (peak force adhering to the probe on the second compression) was added. Noodle hardness was defined as the peak force attained during the first compression.

Noodle firmness and hardness variables differed as follows. Firmness was the peak force required to penetrate $1 \mathrm{~mm}$ into the noodlc with a blade, whereas hardness was the peak force required to compress a noodle to $70 \%$ of its height with a blunt probe. Although both methods measure peak force, the results are from 
different portions of the noodle based on the depth and contact surface of the probe.

\section{Statistical Analysis}

Statistical computations were made using SAS v. 8.2 for PC (SAS Institute, Cary, NC). Analysis of variance was conducted using PROC GLM. Main effects in the model were environment (E), replicate within environment, genotype (cultivar or breeding line, G), and GBSS alleles (alleles at the $w x-A I$ and $w x-B I$ loci). The $\mathrm{G} \times \mathrm{E}$ and GBSS allele $\times \mathrm{E}$ interactions also were included. The $F$ statistic was used to determine statistical significance. For environment, the replicate within environment term was used to calculate the $F$ statistic. For genotype, the $\mathrm{G} \times \mathrm{E}$ term, when signilicant, was used. When the $\mathrm{G} \times \mathrm{E}$ interaction was not significant, the mean square error was used as the denominator to calculate the $F$ statistic. Significance of the GBSS allelic effect was estimated using the GBSS $\times \mathrm{E}$ term as the denominator in calculation of $F$ values. For traits in which significant genotypic effects were observed by analysis of variance, mean values were compared by calculation of least significant differences (LSD, $P=0.05$ ).

Phenotypic correlations among traits were calculated after fïst averaging genotypic responses by environment, only for those variables for which significant differences were observed among the genotypes. Genetic correlations (Kempthorne 1957) were calculated using the PROC MANOVA, and the cross-products method in SAS. Partial genetic correlations were calculated to examine genetic relationships between traits after removal of effects due to variable flour protein contents. Partial correlations were calculated using procedures given by Lowry (http://faculty.vassar:edu/ lowry/webtext.himl).

\section{RESUITS AND DISCUSSION}

The study revealed significant variation due to environment for all grain traits and for all noodle color characteristics (both fresh and after $24 \mathrm{hr}$ ) of both types of noodles, with the exception of yellow alkaline noodle $b^{*}$ value, $24 \mathrm{hr}$ (Tables I-III). Significant genotypic differences were observed for every noodle color trait in both types of noodle, while the significant $\mathrm{G} \times \mathrm{E}$ interactions were detected for some $\mathrm{L}^{*}$ values (initial in yellow alkaline, and both intial and $24 \mathrm{hr}$, in white salted), and both initial and 24-hr $\mathrm{a}^{\text {* }}$ values of white salted noodles. As $\mathrm{L}^{*}$ (noodle brightness) is an important quality trait for many types of noodles (Miskelly 1996), the significant $\mathrm{G} \times \mathrm{E}$ interaction necessitates testing of breeding lines in multiple environments before an accurate assessment of noodle color potential is established. Significant differences in noodle color traits also were observed among GBSS allelic classes (Tables II and III). A comparison (not shown) of mean values of noodle color traits for cultivars and experimental lines indicated noodles from the hard white wheat cultivar Lakin were the brightest (highest $\mathrm{L}^{*}$ value) in both yellow alkaline and white salted noodle procedures. The 24-hr L* values of Lakin were statistically different from those of all other lines in the study (not shown). Lakin has been reported to possess low levels of grain polyphenol oxidase (Martin et al 2001), no doubt the source of its bright noodle color traits. Trego, another hard white wheat, had the second highest mean $L^{*}$ scores. Several hard red winter wheats, including the cultivar Ike and several experimental lines, did not differ significantly from Trego. High 24-hr $L^{*}$ values (brightness) are desirable for both yellow alkaline and white salted noodles (Miskelly 1996). For yellow alkaline noodles, high 24-hr $b^{*}$ values (yellowness) also are desirable, while for white salted noodles, a creamy white color (and hence lower $b^{*}$ ) is necessary. Lakin demonstrated the highest $24-\mathrm{hr} b^{*}$ value in the yellow alkaline test, significantly higher than all but two of the remaining lines in the study. Lakin also demonstrated one of the lowest 24-ht $b^{*}$ values in the white salted noodle test, suggesting that it would be acceptable in a variety of noodle applications. The lowest 24-hr $b^{*}$ value in the white salted noodle assay was recorded by an experimental line 96MD711049. This line, however, had one of the lowest 24-hr L* values in both tests, indicating that noodle color traits do not always vary simultaneously.

To further investigate the interrelationships of noodle color traits, phenotypic and genetic correlations were calculated between all color variables from both noodle color assays, and between noodle color traits and grain weight, grain hardness, and flour protein concentrations. Phenotypic correlations assess similar responses of variables due to combined genetic and environmental effects. Similar environmental responses, however, might arise from different genes within different genetic backgrounds. Genetic corre-

TABLE II

Mean Square Values from Analysis of Variance for Yellow Alkaline Noodle Color Traits of 38 Hard Winter Wheats Grown at Three Nebraska Locations in 2000

\begin{tabular}{|c|c|c|c|c|c|c|c|}
\hline \multirow[b]{2}{*}{ Source of Variation } & \multirow[b]{2}{*}{ df } & \multicolumn{2}{|c|}{$L^{*}$ Value } & \multicolumn{2}{|c|}{$a^{*}$ Value } & \multicolumn{2}{|c|}{ b* Value } \\
\hline & & Initial & $24 \mathrm{hr}$ & Initial & $24 \mathrm{hr}$ & Initial & $24 \mathrm{hr}$ \\
\hline Environment (E) & 2 & $18.66 *$ & $967.78 *$ & $6.88 *$ & $106.60 *$ & $29.46 *$ & 55.10 \\
\hline Replicate within E & 6 & $2.03 *$ & $10.21 *$ & $0.94 *$ & $2.01 *$ & $3.48 *$ & $27.84 *$ \\
\hline Genotype & 37 & $3.91 \%$ & $26.65 \%$ & $0.89 *$ & $2.10 *$ & $7.15 \%$ & $11.93 *$ \\
\hline GBSS alleles & 3 & $7.19 *$ & $14.14 *$ & 0.61 & $1.99 *$ & 6.00 & $2.99 *$ \\
\hline Genotype $\times \mathrm{E}$ & 74 & $0.64 *$ & 4.02 & 0.26 & 0.23 & 0.98 & 1.96 \\
\hline GBSS alleles $\times \mathrm{E}$ & 6 & 0.98 & 2.88 & 0.33 & 0.16 & 1.63 & 0.63 \\
\hline Error & 216 & 0.42 & 2.91 & 0.23 & 0.24 & 0.63 & 1.56 \\
\hline
\end{tabular}

a *, Significant at $P=0.05$.

TABLE III

Mean Square Values from Analysis of Variance for White Salted Noodle Color Traits of 38 Hard Winter Wheats Grown at Three Nebraska Locations in 2000 ${ }^{\mathrm{a}}$

\begin{tabular}{|c|c|c|c|c|c|c|c|}
\hline \multirow[b]{2}{*}{ Source of Variation } & \multirow[b]{2}{*}{ df } & \multicolumn{2}{|c|}{ L* Value } & \multicolumn{2}{|c|}{$a^{*}$ Value } & \multicolumn{2}{|c|}{$b^{*}$ Value } \\
\hline & & Initial & $24 \mathrm{hr}$ & Initial & $24 \mathrm{hr}$ & Initial & $24 \mathrm{hr}$ \\
\hline Environment (E) & 2 & $14.81 \%$ & $347.23 *$ & $6.05 *$ & $31.91 *$ & $41.96 *$ & $415.24 *$ \\
\hline Replication within E & 6 & $1.98 *$ & $19.38 *$ & $0.13 *$ & $1.60 *$ & $1.64 *$ & $36.30 *$ \\
\hline Genotype & 37 & $2.23 *$ & $11.42 *$ & 0.33 & $1.05 *$ & $7.00 *$ & $9.98 *$ \\
\hline GBSS alleles & 3 & $4.43 *$ & 11.85 & $0.70 *$ & $1.90 *$ & 2.21 & $10.66^{*}$ \\
\hline Genotype $\times \mathrm{E}$ & 74 & $0.37 *$ & $2.14 *$ & $0.05 *$ & $0.17 *$ & 0.34 & 1.63 \\
\hline GBSS alleles $\times \mathrm{E}$ & 6 & 0.50 & 2.54 & 0.08 & 0.25 & 1.17 & 0.5 \\
\hline Error & 216 & 0.2 & 1.56 & 0.03 & 0.1 & 0.41 & 1.52 \\
\hline
\end{tabular}

a *, Significant at $P=0.05$. 
lations, therefore, assess only the genetic relationships between pairs of traits (Falconer 1960). Partial genetic correlations also were calculated to examine the genetic relationship between trait pairs independent of their joint relationships to flour protein contents. Results (Table IV) demonstrated highly significant positive phenotypic and genetic correlations between both $\mathrm{L}^{*}$ measurements of yellow alkaline noodles and those of white salted noodles. The a* (redness) values of yellow alkaline noodles showed significant positive phenotypic and genetic correlations with those of white salted noodles, and significant negative correlations with $L^{*}$ values of both types of noodle. Noodle $b^{*}$ values were largely independent of all $\mathrm{L}^{*}$ and $\mathrm{a}^{*}$ values. Both initial and final $b^{*}$ values of yellow alkaline noodles showed positive phenotypic correlations with those of white salted noodles, but the genetic correlations were lower in magnitude. The correlations of the yellow alkaline initial $b^{*}$ values with white salted noodle $b^{*}$ values (Table IV) were much higher than those of the $24-\mathrm{hr}^{*}$ * value with the white salted noodle $\mathrm{b}^{*}$ values. The correlations of $b^{*}$ values suggest that it might be difficult to identify genotypes capable of providing optimal color in both yellow alkaline and white salted noodles. However, the lower correlations of yellow alkaline 24-hr b* values with white salted noodles 24-hr $\mathrm{b}^{*}$ values, and the observation that Lakin produced the most optimal results in both tests suggests that occasional, though perhaps rare, genotypes will be discovered that perform well in a variety of applications.
In general, genctic correlations among noodle color traits were of lower magnitude than the phenotypic correlations. In addition, partial correlations (Table IV) indicated the genetic correlations observed among $\mathrm{L}^{*}$ and $\mathrm{a}^{*}$ values largely were duc to simultaneous relationships with protein content. Partial genetic correlations between $b^{*}$ values in yellow alkaline and white salted applications were, however, not due to protein content effects, as they were nearly equal in magnitude to the genetic correlations. This indicates biochemical factors other than protein content are influencing noodle $b^{*}$ values.

Noodle color traits showed some moderate, though significant, correlations with grain weight and with grain hardness (Table IV). Flour protein concentration showed significant negative phenotypic and genetic correlations with both $\mathrm{L}^{*}$ and both $\mathrm{b}^{*}$ values for both types of noodles, and was positively correlated with all $\mathrm{a}^{*}$ values. Thus, in the selection of wheats for desirable noodle color traits, the protein content of the tested sample must be considered. Habernicht et al (2002) also noted that protein concentrations affected noodle color traits.

Noodle textural traits were investigated only in white salted noodles. In contrast to the observations with noodle color traits, the environmental modification of noodle textural traits was far less evident (Table V).

In the analysis of variance, significant environmental variation was detected only for the noodle hardness and water uptake traits. The replicate within environment variation was significant for most

TABLE IV

Phenotypic $^{\text {a }(t o p), ~ G e n e t i c ~(m i d d l e), ~ a n d ~ P a r t i a l ~ G e n e t i c ~ C o r r e l a t i o n s ~}(r)$ Between Yellow Alkaline Noodle Color, White Salted Noodle Color, and Grain and Flour Characteristics

\begin{tabular}{|c|c|c|c|c|c|c|c|c|c|}
\hline & \multicolumn{9}{|c|}{ White Salted Noodles } \\
\hline & \multicolumn{2}{|c|}{$\mathrm{L}^{*}$ Value } & \multicolumn{2}{|c|}{ a* Value } & \multicolumn{2}{|c|}{ b* Value } & \multirow{2}{*}{$\begin{array}{c}\text { Grain } \\
\text { Wt }\end{array}$} & \multirow{2}{*}{$\begin{array}{c}\text { Grain } \\
\text { Hardness }\end{array}$} & \multirow{2}{*}{$\begin{array}{c}\text { Flour } \\
\text { Protein }\end{array}$} \\
\hline & Initial & $24 \mathrm{hr}$ & Initial & $24 \mathrm{hr}$ & Initial & $24 \mathrm{hr}$ & & & \\
\hline \multicolumn{10}{|c|}{ Yellow alkaline noodles } \\
\hline \multicolumn{10}{|c|}{ L* Value } \\
\hline \multirow[t]{2}{*}{ Initial } & 0.89 & 0.71 & -0.59 & -0.59 & -0.40 & -0.34 & 0.45 & -0.18 & -0.30 \\
\hline & 0.59 & 0.40 & -0.39 & -0.43 & 0.23 & 0.27 & 0.20 & 0.13 & -0.40 \\
\hline \multirow[t]{2}{*}{$24 \mathrm{hr}$} & 0.67 & 0.94 & -0.82 & -0.81 & -0.52 & -0.57 & 0.72 & -0.44 & -0.66 \\
\hline & 0.52 & 0.67 & -0.55 & -0.60 & 0.16 & 0.16 & 0.25 & 0.17 & -0.68 \\
\hline \multicolumn{10}{|l|}{ a* Value } \\
\hline \multirow{2}{*}{ Initial } & -0.64 & -0.69 & 0.75 & 0.75 & 0.17 & 0.18 & -0.55 & 0.25 & 0.67 \\
\hline & -0.39 & -0.40 & 0.43 & 0.39 & 0.00 & -0.06 & -0.25 & -0.03 & 0.51 \\
\hline \multirow[t]{2}{*}{$24 \mathrm{hr}$} & -0.53 & -0.80 & 0.90 & 0.91 & 0.44 & 0.46 & -0.70 & 0.53 & 0.79 \\
\hline & -0.42 & -0.27 & 0.43 & 0.47 & -0.04 & 0.24 & -0.28 & -0.05 & 0.39 \\
\hline \multicolumn{10}{|l|}{$b^{*}$ Value } \\
\hline \multirow[t]{2}{*}{ Initial } & -0.21 & -0.32 & 0.30 & 0.30 & 0.82 & 0.54 & -0.28 & 0.32 & 0.15 \\
\hline & 0.25 & 0.33 & -0.21 & -0.26 & 0.40 & 0.26 & 0.06 & 0.41 & -0.25 \\
\hline \multirow[t]{2}{*}{$24 \mathrm{hr}$} & 0.01 & -0.12 & 0.07 & 0.22 & 0.51 & 0.48 & -0.25 & 0.26 & 0.16 \\
\hline & 0.34 & 0.29 & -0.28 & -0.24 & 0.24 & 0.37 & 0.00 & 0.39 & -0.19 \\
\hline \multirow[t]{2}{*}{ Grain wt } & 0.47 & 0.74 & -0.34 & -0.68 & -0.42 & -0.53 & $\ldots$ & -0.52 & -0.64 \\
\hline & 0.30 & 0.33 & -0.33 & -0.37 & -0.09 & -0.04 & $\ldots$ & -0.39 & -0.45 \\
\hline \multirow[t]{2}{*}{ Grain hardness } & -0.10 & -0.42 & 0.40 & 0.43 & 0.32 & 0.45 & -0.51 & $\ldots$ & 0.46 \\
\hline & 0.22 & 0.10 & 0.03 & 0.05 & 0.32 & 0.30 & -0.39 & $\ldots$ & 0.06 \\
\hline \multirow[t]{2}{*}{ Flour protein } & -0.33 & -0.63 & 0.72 & 0.75 & 0.16 & 0.28 & -0.64 & 0.47 & $\ldots$ \\
\hline & -0.57 & -0.71 & 0.64 & 0.66 & -0.02 & -0.10 & -0.45 & 0.06 & $\ldots$ \\
\hline
\end{tabular}

a Phenotypic correlations $>0.20$ or $<-0.20$ were significant at $P=0.05$.

TABLE V

Mean Square Values from Analysis of Variance for White Salted Noodle Textural Traits of 38 Hard Winter Wheats Grown at Three Nebraska Locations in $2000^{\mathrm{a}}$

\begin{tabular}{|c|c|c|c|c|c|c|c|c|c|c|c|}
\hline Source of Variation & df & Firmness & $\begin{array}{l}\text { Cutting } \\
\text { Force }\end{array}$ & $\begin{array}{l}\text { Cutting area } \\
\text { (work to cut) }\end{array}$ & $\begin{array}{l}\text { Noodle } \\
\text { Thickness }\end{array}$ & $\begin{array}{c}\text { Noodle } \\
\text { Hardness }\end{array}$ & $\begin{array}{l}\text { Stickiness } \\
\text { Force }\end{array}$ & $\begin{array}{c}\text { Stickiness } \\
\text { Area }\end{array}$ & Springiness & Resilience & $\begin{array}{l}\text { Water } \\
\text { Uptake }\end{array}$ \\
\hline Environment (E) & 2 & 16,238 & 17,654 & 105,506 & 0.06 & $3,156,528 *$ & 2,217 & 11,671 & 0.00007 & 0.016 & $1,051.2 *$ \\
\hline Replicate within E & 6 & $3,846 *$ & $173,263^{*}$ & $76,671^{*}$ & $0.04 *$ & 106,472 & 901 & 3,036 & $0.005^{*}$ & 0.004 & $88.8 *$ \\
\hline Genotype & 37 & $9,772 *$ & $54,855^{*}$ & $21,650 *$ & $0.02 *$ & $146,404^{*}$ & 491 & 939 & 0.002 & $0.001 *$ & $44.1 *$ \\
\hline GBSS alleles & 3 & $61,455^{*}$ & $19,9179 *$ & $74,470 *$ & $0.08 *$ & $719,706^{*}$ & $2,700 *$ & $3,872 *$ & 0.002 & $0.005^{*}$ & 41.3 \\
\hline Genotype $\times \mathrm{E}$ & 74 & 1,128 & 14,115 & 8,676 & 0.004 & $86,137 *$ & 364 & 748 & 0.002 & 0.0005 & 21.5 \\
\hline GBSS alleles $\times \mathrm{E}$ & 6 & 1,079 & 32,274 & $24,263^{*}$ & 0.008 & $223,811^{*}$ & 235 & 712 & 0.002 & 0.0009 & 36.4 \\
\hline Error & 216 & 832 & 1,4015 & 9,567 & 0.005 & 61,766 & 403 & 790 & 0.002 & 0.0004 & 22.6 \\
\hline
\end{tabular}

a*, Significant at $P=0.05$. 
textural traits, indicating that variation within test sites (fields) is perhaps more important than variation between sites for textural traits. Significant variation due to genotype (Table V) was observed for 7 of the 10 measured traits, lacking only stickiness force, stickiness area, and springiness. Similarly, 8 of the 10 textural traits showed significant variation due to GBSS alleles. Genotype-byenvironment and GBSS alleles-by-environment interactions were largely nonsignificant; a significant interaction was observed in each case only for noodle firmness. Genotype-by-environment interactions typically are significant for most wheat products (Baenziger et al 1985; Bassett et al 1989; Peterson et al 1998), and significant interactions were observed for the noodle color traits. Hence, the observation of few interactions modifying noodle textural features is unique. Textural measurements require special- ized equipment, actual cooking of noodles, and are more complicated and expensive than noodle color assays. The predominance of genotypic variation we observed for textural traits suggests a strategy for breeding wheats for optimal noodle quality could involve early generation color testing of samples from multiple environments, but testing of fewer samples, derived either from composites of multiple location samples or single environments, might suffice for textural traits.

Interrelationships among white salted noodle textural traits, and between textural and color, grain, and flour traits (Tables VI and VII) were calculated for phenotypic, genetic, and partial genetic correlations. A number of significant correlations were observed between cutting force, cutting area, and noodle $\mathrm{L}^{*}$ and $\mathrm{a}^{*}$ values. These same variables also were correlated with protein content,

TABLE VI

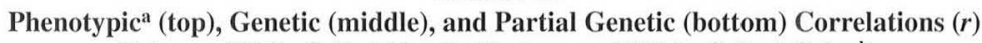
Between White Salted Noodle Texture and White Salted Color ${ }^{b}$

\begin{tabular}{|c|c|c|c|c|c|c|}
\hline & \multicolumn{2}{|c|}{ L*Value } & \multicolumn{2}{|c|}{ a* Value } & \multicolumn{2}{|c|}{$b^{*}$ Value } \\
\hline & Initial & $24 \mathrm{hr}$ & Initial & $24 \mathrm{hr}$ & Initial & $24 \mathrm{hr}$ \\
\hline \multirow[t]{3}{*}{ Noodle firmness } & -0.13 & -0.21 & 0.14 & 0.13 & -0.10 & 0.12 \\
\hline & -0.25 & -0.19 & 0.17 & 0.20 & -0.07 & -0.08 \\
\hline & -0.14 & -0.03 & 0.03 & 0.05 & -0.07 & -0.06 \\
\hline \multirow[t]{3}{*}{ Cutting force } & -0.39 & -0.30 & 0.32 & 0.32 & 0.10 & 0.06 \\
\hline & -0.37 & -0.26 & 0.33 & 0.35 & 0.02 & 0.04 \\
\hline & -0.05 & 0.27 & -0.07 & -0.05 & 0.04 & 0.12 \\
\hline \multirow[t]{3}{*}{ Cutting area (work to cut) } & -0.39 & -0.44 & 0.46 & 0.51 & 0.19 & 0.17 \\
\hline & -0.37 & -0.26 & 0.36 & 0.38 & 0.03 & 0.01 \\
\hline & -0.05 & 0.27 & -0.03 & -0.01 & 0.05 & 0.09 \\
\hline \multirow[t]{3}{*}{ Noodle thickness } & -0.20 & -0.24 & 0.30 & 0.37 & 0.25 & 0.17 \\
\hline & -0.23 & -0.11 & 0.17 & 0.21 & 0.13 & 0.01 \\
\hline & -0.01 & 0.26 & -0.11 & -0.06 & 0.15 & 0.05 \\
\hline \multirow[t]{3}{*}{ Noodle hardness } & -0.01 & -0.31 & 0.31 & 0.41 & 0.16 & 0.13 \\
\hline & -0.15 & -0.08 & 0.12 & 0.15 & -0.10 & 0.04 \\
\hline & -0.11 & -0.01 & 0.08 & 0.12 & -0.09 & 0.05 \\
\hline \multirow[t]{3}{*}{ Resilience } & -0.13 & 0.12 & -0.24 & -0.30 & 0.09 & 0.02 \\
\hline & -0.11 & 0.04 & 0.01 & 0.01 & 0.08 & 0.02 \\
\hline & -0.07 & 0.16 & -0.07 & -0.07 & 0.08 & 0.03 \\
\hline \multirow[t]{3}{*}{ Water uptake } & 0.12 & 0.37 & -0.43 & -0.56 & -0.19 & -0.12 \\
\hline & 0.07 & 0.16 & -0.11 & -0.14 & 0.06 & -0.02 \\
\hline & -0.01 & 0.09 & -0.03 & -0.07 & 0.06 & -0.03 \\
\hline
\end{tabular}

a Phenotypic correlations $>0.20$ or $<-0.20$ were significant at $P=0.05$.

b Includes only those variables with statistically significant differences among lines.

TABLE VII

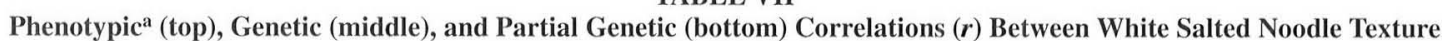
and Grain and Flour Characteristics ${ }^{b}$

\begin{tabular}{|c|c|c|c|c|c|c|c|c|c|}
\hline & $\begin{array}{c}\text { Grain } \\
\text { Wt }\end{array}$ & $\begin{array}{c}\text { Grain } \\
\text { Hardness }\end{array}$ & $\begin{array}{l}\text { Flour } \\
\text { Protein }\end{array}$ & $\begin{array}{l}\text { Cutting } \\
\text { Force }\end{array}$ & $\begin{array}{l}\text { Cutting Area } \\
\text { (work to cut) }\end{array}$ & $\begin{array}{c}\text { Noodle } \\
\text { Thickness }\end{array}$ & $\begin{array}{c}\text { Noodle } \\
\text { Hardness }\end{array}$ & Resilience & $\begin{array}{l}\text { Water } \\
\text { Uptake }\end{array}$ \\
\hline \multirow[t]{3}{*}{ Noodle firmness } & -0.31 & -0.03 & 0.19 & -0.21 & 0.07 & -0.49 & 0.41 & -0.25 & -0.14 \\
\hline & -0.13 & -0.04 & 0.24 & 0.05 & 0.06 & -0.18 & 0.15 & -0.12 & -0.06 \\
\hline & -0.02 & -0.05 & & -0.12 & -0.10 & -0.31 & 0.13 & -0.15 & -0.03 \\
\hline \multirow[t]{3}{*}{ Cutting force } & -0.10 & 0.01 & 0.39 & & 0.87 & 0.72 & 0.01 & 0.32 & -0.23 \\
\hline & -0.33 & 0.08 & 0.58 & & 0.96 & 0.78 & 0.17 & 0.35 & -0.20 \\
\hline & -0.09 & 0.05 & & & 0.94 & 0.74 & 0.13 & 0.36 & -0.14 \\
\hline \multirow[t]{3}{*}{ Cutting area (work to cut) } & -0.31 & 0.15 & 0.55 & & & 0.73 & 0.30 & 0.09 & -0.47 \\
\hline & -0.31 & 0.07 & 0.58 & & & 0.83 & 0.19 & 0.30 & -0.29 \\
\hline & -0.07 & 0.05 & & & & 0.80 & 0.17 & 0.30 & -0.26 \\
\hline \multirow[t]{3}{*}{ Noodle thickness } & -0.10 & 0.24 & 0.33 & & & & 0.09 & 0.17 & -0.41 \\
\hline & -0.18 & 0.05 & 0.39 & & & & 0.08 & 0.30 & -0.20 \\
\hline & -0.01 & 0.03 & & & & & 0.05 & 0.28 & -0.16 \\
\hline \multirow[t]{3}{*}{ Noodle hardness } & -0.30 & 0.26 & 0.50 & & & & & -0.48 & -0.54 \\
\hline & 0.01 & -0.07 & 0.10 & & & & & -0.33 & -0.18 \\
\hline & 0.06 & -0.08 & & & & & & -0.34 & -0.17 \\
\hline \multirow[t]{3}{*}{ Resilience } & 0.28 & -0.13 & -0.41 & & & & & & 0.30 \\
\hline & -0.11 & 0.06 & 0.10 & & & & & & 0.13 \\
\hline & -0.07 & 0.06 & & & & & & & 0.15 \\
\hline \multirow[t]{3}{*}{ Water uptake } & 0.30 & -0.26 & -0.26 & & & & & & \\
\hline & 0.04 & -0.02 & -0.14 & & & & & & \\
\hline & -0.03 & -0.01 & & & & & & & \\
\hline
\end{tabular}

a Phenotypic correlations $>0.20$ or $<-0.20$ were significant at $P=0.05$.

${ }^{b}$ Includes only those variables with statistically significant differences among lines. 
but the partial correlations with noodle $24-\mathrm{hr} \mathrm{L}^{*}$ values indicated similar responses to protein did not explain the entire relationship. Cutting force, cutting area, and noodle thickness showed high phenotypic, genetic, and partial genetic correlations, indicating these traits are conditioned by similar genetic mechanisms, and these mechanisms are independent of those conditioning flour protein content. Noodle firmness showed significant negative phenotypic correlations with noodle thickness and resiliency, and was positively correlated with noodle hardness. However, the genetic correlations werc much lower, indicating the traits merely are responding in a similar fashion to environments. There was no relationship between noodle firmness and protein content. Water uptake was largely independent of the other textural measures, with the exception of some low negative correlations with noodle thickness and noodle hardness. A number of variables from the cutting test and from the texture profile analysis no doubt contribute to final product appeal to consumers. While many variables were intercorrelated (Tables VI and VII), it appears the correlations were not large enough to warrant reliance on a single measure alone. Combinations of variables (Epstein et al 2002) are necessary to forecast product quality.

Mean values of each GBSS allelic class (Tables VIII, IX, X) revealed a clear relationship between noodle textural properties and the presence of null alleles at multiple $w x$ loci. Noodle firmness decreased in the order wild-type $=w x-A I$ null $>w x-B I$ null $>w x-A I$ null $+w x-B I$ null (double nulls). Of the 10 firmest lines (data not shown), five were wild-type, with the remaining five carrying the $w x-A l$ null only. Factors other than GBSS alleles, however, also contribute to noodle firmness. One wild- type line (data not shown) was among the 10 softest lines. Also, one double null line (null alleles at both $w x-A l$ and $w x-B l$ loci) was within the top 10 firmest lines. The double null class also produced the least hard and sticky noodles.

No differences in flour protein content were observed among the GBSS allelic classes. Grain hardness of the $w x-B I$ null class was significantly higher than that of the other groups, but the mean value likely would be of no practical consideration during milling. Thus, observed differences in noodle texture among these classes must derive from differences in starch properties. There were some statistically significant differences among GBSS allelic classes for noodle color traits, but there were no consistent trends. Wild-type lines had the lowest mean $L^{*}$ and the highest $b^{*}$ values in both yellow alkaline and white salted noodles. Perhaps the more crystalline nature of amylopectin, lower in concentration in wild-type starch, confers some advantage in noodle color tests.

The role of the waxy null alleles on noodle quality has been a topic of considerable discussion among North American wheat breeders. The utility of such alleles as a means to modify noodle quality now is indisputable. Noda et al (2001), Epstein et al (2002), and the present investigation, all demonstrated softer noodle texture associated with the presence of one or more null alleles, and the concomitant reductions in flour starch amylose concentrations. As noted by Epstein et al (2002), softer texture is desired in udon noodles, but in many other types of noodles, a firmer, harder bite is desired. For udon or other soft textured noodles, they suggested deployment of one or more $w x$ null alleles, while for Chinese and other types of white salted noodles, and for yellow alkaline noodles, selection against null alleles was suggested. The

TABLE VIII

Granule-Bound Starch Synthase Genotypic Means for Yellow Alkaline Noodle Color ${ }^{a}$

\begin{tabular}{|c|c|c|c|c|c|c|}
\hline \multirow[b]{2}{*}{ GBSS Alleles } & \multicolumn{2}{|c|}{$\mathrm{L} *$ Value } & \multicolumn{2}{|c|}{$a^{*}$ Value } & \multicolumn{2}{|c|}{$b^{*}$ Value } \\
\hline & Initial & $24 \mathrm{hr}$ & Initial & $24 \mathrm{hr}$ & Initial & $24 \mathrm{hr}$ \\
\hline$w x-A 1$ null & $85.92 b$ & $73.55 \mathrm{ab}$ & $-2.47 \mathrm{a}$ & $-0.33 \mathrm{a}$ & $24.28 \mathrm{a}$ & $28.46 \mathrm{ab}$ \\
\hline$w x-B 1$ null & $86.13 \mathrm{ab}$ & $73.96 \mathrm{a}$ & $-2.58 \mathrm{a}$ & $-0.42 \mathrm{a}$ & $24.42 \mathrm{a}$ & $28.27 \mathrm{~b}$ \\
\hline Wild-type & $86.45 \mathrm{a}$ & $74.42 \mathrm{a}$ & $-2.66 \mathrm{a}$ & $-0.67 b$ & $23.85 b$ & $28.26 b$ \\
\hline
\end{tabular}

a Means followed by the same letter did not differ at $P=0.05$.

TABLE IX

Granule-Bound Starch Synthase Genotypic Means for White Salted Noodle Color ${ }^{\text {a }}$

\begin{tabular}{|c|c|c|c|c|c|c|}
\hline \multirow[b]{2}{*}{ GBSS Alleles } & \multicolumn{2}{|c|}{$\mathrm{L} *$ Value } & \multicolumn{2}{|c|}{$a *$ Value } & \multicolumn{2}{|c|}{$b^{*}$ Value } \\
\hline & Initial & $24 \mathrm{hr}$ & Initial & $24 \mathrm{hr}$ & Initial & $24 \mathrm{hr}$ \\
\hline$w x-A 1$ null & $87.47 \mathrm{~b}$ & $79.55 b$ & $-0.56 b$ & $0.25 \mathrm{a}$ & $18.04 \mathrm{ab}$ & $23.50 \mathrm{~b}$ \\
\hline$w x-B 1$ null & $87.68 \mathrm{a}$ & $80.17 \mathrm{ab}$ & $-0.70 \mathrm{a}$ & $0.01 \mathrm{~b}$ & $18.26 \mathrm{a}$ & $23.96 \mathrm{a}$ \\
\hline$w x-A I$ null $+w x-B I$ null & $87.37 \mathrm{~b}$ & $79.63 b$ & $-0.51 \mathrm{c}$ & $0.33 a$ & $18.19 \mathrm{a}$ & $23.42 b$ \\
\hline Wild-type & $87.85 a$ & $80.28 \mathrm{a}$ & $-0.66 a b$ & $0.08 b$ & $17.91 \mathrm{~b}$ & $23.10 \mathrm{~b}$ \\
\hline
\end{tabular}

${ }^{a}$ Means followed by the same letter did not differ at $P=0.05$.

TABLE X

Granule-Bound Starch Synthase Genotypic Means for White Salted Noodle Quality Traits

\begin{tabular}{|c|c|c|c|c|}
\hline GBSS Alleles & $w x-A 1$ null & $w x-B 1$ null & $w x-A 1$ null $+w x-B 1$ null & Wild-type \\
\hline Flour protein $(\%)$ & $12.03 \mathrm{a}$ & $12.16 \mathrm{a}$ & $11.96 \mathrm{a}$ & $11.88 \mathrm{a}$ \\
\hline Grain hardness (units) & $69.20 \mathrm{~b}$ & $71.65 \mathrm{a}$ & $69.84 b$ & $69.72 b$ \\
\hline Grain weight (mg) & $26.85 a$ & $27.13 \mathrm{a}$ & $27.11 \mathrm{a}$ & $26.34 b$ \\
\hline Noodle firmness (g) & $483.35 \mathrm{a}$ & $455.56 b$ & $435.09 c$ & $488.21 \mathrm{a}$ \\
\hline Cutting force $(\mathrm{g})$ & $1,021.48 \mathrm{ab}$ & $1,027.75 \mathrm{ab}$ & $1,077.98 \mathrm{a}$ & $960.82 b$ \\
\hline Cutting area (work to cut, g/sec) & $825.80 \mathrm{a}$ & $794.24 a$ & $827.31 \mathrm{a}$ & $786.59 a$ \\
\hline Noodle thickness (mm) & $1.71 \mathrm{~b}$ & $1.71 \mathrm{~b}$ & $1.75 \mathrm{a}$ & $1.68 b$ \\
\hline Noodle hardness (g) & $2769.01 \mathrm{a}$ & $2,674.46 \mathrm{ab}$ & $2,591.85 b$ & $2,779.75 a$ \\
\hline Stickiness force (g/sec) & $-119.66 \mathrm{a}$ & $-114.30 \mathrm{a}$ & $-107.99 b$ & $-119.31 \mathrm{a}$ \\
\hline Stickiness area (g/mm) & $-123.59 a b$ & $-120.99 a b$ & $-111.89 b$ & $-128.05 a$ \\
\hline Springiness (ratio) & $0.89 \mathrm{a}$ & $0.89 \mathrm{a}$ & $0.89 \mathrm{a}$ & $0.89 \mathrm{a}$ \\
\hline Resilience (ratio) & $0.37 \mathrm{ab}$ & $0.37 \mathrm{ab}$ & $0.38 \mathrm{a}$ & $0.36 \mathrm{~b}$ \\
\hline Water uptake (\%) & $121.84 \mathrm{a}$ & $123.69 \mathrm{a}$ & $122.75 a$ & $122.77 \mathrm{a}$ \\
\hline
\end{tabular}

a Means followed by the same letter did not differ at $P=0.05$. 
present study suggests selection for or against the null alleles (depending on desired noodle firmness) could result in a population enriched in the desired attribute. Fixation of the alleles will not necessarily guarantee a specific firmness level, as a few exceptions existed. An enriched population would, however, reduce the number of lines requiring extensive textural analyses. Udon noodles typically are produced from soft-grained wheat; however, based on the range of noodle firmness observed in this study, an obvious question to address in future research is whether acceptable udon noodles could be produced from hard white lines harboring one or more $w x$ null alleles. This study, therefore, confirms the observations of Epstein et al (2002) that softer noodle texture results from the presence of null alleles at the $w x$ loci. It also extends those observations by demonstrating that the ellect is fairly consistent over production environments. Both breeding programs and end users could, thercfore, use GBSS genotypes to forecast final noodle texture of breeding lines or commercial grain samples.

\section{CONCLUSIONS}

Noodle color in both yellow alkaline and white salted noodle tests was significantly modified by environmental and genotypic cffects, and by $\mathrm{G} \times \mathrm{E}$ interactions. Noodle $\mathrm{L}^{*}$ values (noodle brightness) were significantly and positively correlated in the two noodle applications. Noodle $b^{*}$ values also were significantly positively correlated, but this might be a disadvantage when attempting to develop wheats for a variety of noodle applications with diverse color requirements. Nevertheless, specific genotypes, namely the hard white cultivar Lakin, produced color properties suitable for both applications. White salted noodle hardness and water uptake were the only textural features significantly affected both by genotype and environment. Several additional textural features also were modificd by genotypic factors, principally the number of null alleles at the $w x$ loci. For markets desiring firmer noodles, selection against null alleles at the waxy loci is warranted. For markets desiring softer textured noodles, their incorporation should be attempted. Few significant $\mathrm{G} \times \mathrm{E}$ interactions were observed for noodle textural properties. This study suggests that testing of noodlc color traits lirom multiple environments is necessary during wheat breeding programs to adequately assess the noodle color quality potential of prospective cultivars, while textural features could be measured on samples from fewer environments or from composite samples from several locations.

\section{ACKNOWLEDGMENTS}

We wish to acknowledge the technical assistance of John Moffat, Lori Divis, Vern Hansen, Richard Samson, and Chris Hoagland

\section{LITERATURE CITED}

American Association of Cereal Chemists. 2000. Approved Methods of the AACC, 10th Ed. Methods 39-11, 46-30, 55-31, and 76-21. The Association: St. Paul, MN

Anderson, J. V., and Morris, C. F. 2001. An improved whole-seed assay for screening wheat germplasm for polyphenol oxidase activity. Crop
Sci. 41:1696-1705.

Baenziger, P. S., Clements, R. L., Mclntosh, M. S., Yamazaki, W. T., Starling, T. M., Sammons, D. J., and Johnson, J. W. 1985. Ellfect of cultivar, environment and their interaction and stability analyses on milling and baking quality of solt red winter wheal. Crop Sci. 25:5-8.

Bassett, L. M., Allan, R. E., and Rubenthaler, G. L. 1989. Genolype $x$ environment interactions on soft white winter wheal quality. Agron. J. 81:955-960).

Batey, I. L., Curtin, B. M., and Moore, S. A. 1997. Optimizalion of Rapid-Visco Analyser test conditions for predicting Asian noodle quality. Cercal Chem. 74:497-501.

Bhaltacharya, M., and Corke, H. 1996. Selection of desirable stalleh pasting properties in wheat for use in white salted or yellow alkaline noodles. Cereal Chem. 73:721-728.

Crosbie, G. B., and Lambe, W. J. 1993. The application of the flour swelling volume test for potential noodle quality 10 whea breeding lines affected by sprouting. J. Cereal Sci. 18:267-276.

Epstein, J., Morris, C. F., and Huber, K. C. 2002. Instrumental texture or white salted noodles prepared from recombinant inbred lines of wheal differing in the three granule bound starch synthase (Waxy) genes. I. Cereal Sci. 35:5!-63.

Falconer, D. S. 1960. Introduction to Quantitative Genelics. Ronald Press: New York

Graybosch, R. A., Peterson, C. J., Hansen, L. E., Rahman, S., Hill, A., and Skerritt, J. 1998. Identification and characterisation of U.S. wheats carrying null alleles at the wx loci. Cereal Chem. 75:1 62-16.5.

Graybosch, R. A., Peterson, C. J., Hareland, G. A., Shelton, D. R., Olewnik, M. C., He, H., and Stearns, M. M. 1999. Relattionships between small-scale wheat quality assays and commercial test bakes. Cereal Chem. 76:428-433.

Habernicht, D. K., Berg, J. E., Carlson, G. R., Wichman, D. M. Kushnak, G. D., Kephart, K. D., Martin, J. M., and Bruckner, P. L. 2002. Pan bread and raw Chinese noodle qualities in hard winter wheal genotypes grown in water-limited environments. Crop Sci. 42:13961403.

Kempthorne, O. 1957. An Introduction to Genetic Statistics. Jobn Wilcy \& Sons: New York.

Kilborn, R. H., and Tipples, K. H. 1981. Canadian test baking procedures. II. GRL-Chorleywood method. Cereal Foods World 26:628-630).

Kruger, J. E. 1996. Noodle quality - What can we lean from the chemistry of breadmaking? Pages 157-167 in: Pasta and Noodle Technology. J. E. Kruger, R. B. Matsuo, and J. W. Dick, eds. Am. Assoc. Cereal Chem.: St. Paul, MN.

Martin, T. J., Frity, A., and Shroyer, J. P. 2001. I akin hard white wheat. http://www.oznet.ksu.edu. Kansas State Agricultural Experiment Station and Cooperative Extension Service Publication L-922. Kannsas State University: Manhattan, KS.

Miskelly, D. M. 1996. The use of alkali for noodle processing. Pages 227-273 in: Pasta and Noodle Technology. J. E. Kruger, R. B. Matsuo, and J. W. Dick, eds. Am. Assoc. Cereal Chem.: St. Paul, MN.

Miura, H., Tanii, S., Nakamura, T., and Watanabe, N. 1994. Cienetic control of amylose content in wheat endosperm starch and dilferential effects of three $W x$ genes. Theor. Appl. Genet. 89:276-280.

Morris, C. F., Shackley, B. J., King, G. E., and Kidwell, K. K. 1997. Genotypic and environmental variation for flour swelling volume in wheat. Coreal Chem. 74:16-21.

Nodi, T., Tohnooka, T., Tayal, S., and Suda, I. 2001. Relationship between physicochemical properties of starches and white salted noodle quality in Japanese wheal flours. Cercal Chem. 78:395-399.

Peterson, C. J., Graybosch, R. A., Shelton, D. R., and Baenziger, P. S. 1998. Baking quality of hard winter wheal: Response of cultivars 10 environment in the Great Plains. Euphytical 100:157-162.

[Received January 28, 2003. Accepted July 15, 2003.] 